Elsevier

BRE 10051

\title{
Maintenance of Chorda Tympani Salt Taste Responses After Nerve Transection in Rats
}

\author{
YASUYUKI KITADA*, ROBERT M. BRADLEY** and CHARLOTTE M. MISTRETTA*** \\ Department of Oral Biology, School of Dentistry, University of Michigan, Ann Arbor, MI 48109 (U.S.A.)
}

(Accepted October 25th, 1983)

Key words: taste - chorda tympani nerve - salt taste responses - nerve transection

\begin{abstract}
To determine whether neurophysiological responses to salts change differentially or in parallel during long recording sessions after nerve transection, we recorded from the cut chorda tympani nerve in rats while stimulating the anterior tongue with $\mathrm{NaCl}, \mathrm{LiCl}$, $\mathrm{NH}_{4} \mathrm{Cl}$ and $\mathrm{KCl}$. In nerve preparations that were not disturbed once recording began, responses were maintained at or above initial magnitudes for an average of $10 \mathrm{~h}$ and declined to $50 \%$ by $15 \mathrm{~h}$. If the cut end of the nerve was redissected when responses began to decline, stable responses were maintained for an average of $12 \mathrm{~h}$, and did not decline to $50 \%$ until $21-24 \mathrm{~h}$. In all rats, responses to the 4 salts altered in parallel for at least $19 \mathrm{~h}$. However in two animals, after $23 \mathrm{~h}$ the responses to $\mathrm{NaCl}$ and $\mathrm{LiCl}$ declined disproportionately, relative to $\mathrm{NH}_{4} \mathrm{Cl}$ and $\mathrm{KCl}$. Therefore in the course of a typical recording session, i.e. 10-12 h, stable taste responses are obtained and even when responses begin to decline after longer periods, response magnitudes to 4 salts alter in parallel. This indicates that receptor membrane components interacting with specific monochloride salts do not degenerate differentially during the first $19 \mathrm{~h}$ after nerve cut.
\end{abstract}

\section{INTRODUCTION}

During postnatal development there are changes in neurophysiological responses to monochloride salts recorded from the rat chorda tympani nerve $7,10,11$. Specifically, the response magnitudes to $\mathrm{NaCl}$ and $\mathrm{LiCl}$ are small in early development, compared to those for $\mathrm{NH}_{4} \mathrm{Cl}$ and $\mathrm{KCl}$. Gradually $\mathrm{NaCl}$ and $\mathrm{LiCl}$ elicit larger response magnitudes that eventually exceed responses to $\mathrm{NH}_{4} \mathrm{Cl}$ and $\mathrm{KCl}$ in the adult. These developmental changes in salt taste responses could relate to the stage of differentiation of taste buds or cells within the bud11,12. We proposed to test this idea by studying responses from taste buds in the early stages of degeneration.

For example, within $3-6 \mathrm{~h}$ after cutting the chorda tympani nerve, degenerative changes reportedly occur in rat taste buds, and the changes appear consistently at $12-24 \mathrm{~h}^{6}$. Certain cells (termed type I or 'dark') degenerate more rapidly than others. There- fore, neurophysiological recordings for long periods after cutting the chorda tympani may provide a preparation for evaluating salt responses from taste buds with cells in various stages of 'dedifferentiation'.

Since gustatory physiologists routinely record for extended periods from cut gustatory nerve bundles and single fibers, such studies also would have important implications for the validity of taste responses from long-term recordings. If the taste response declines substantially by only $2-5 \mathrm{~h}$ after gustatory nerve interruption 9,13 , investigators may need to curtail recording times. Progressive decline in the taste response could be especially problematic if responses to various chemicals were differentially affected. Apparently, glossopharyngeal nerve responses in gerbil to $\mathrm{NH}_{4} \mathrm{Cl}, \mathrm{NaCl}, \mathrm{HCl}$, quinine hydrochloride and sucrose decline with a similar, parallel time course ${ }^{13}$. In rat, data indicate that $\mathrm{NaCl}$ and citric acid responses decline in parallel ${ }^{9}$. However, Beidler ${ }^{2}$ noted that with extremely long recording times, the response of

Correspondence: R. M. Bradley, Department of Oral Biology, School of Dentistry, University of Michigan, Ann Arbor, MI 48109, U.S.A.

* Present address: Department of Physiology, Okayama University, Dental School, Shikato-cho, Okayama-700, Japan.

** To whom reprint requests should be sent. Also from the Department of Physiology, University of Michigan.

*** Also from the Center for Human Growth and Development, and the Center for Nursing Research, School of Nursing. 
the rat chorda tympani to $\mathrm{NaCl}$ may decline differentially until it is actually smaller than the $\mathrm{KCl}$ response.

We studied responses to 4 monochloride salts from the chorda tympani in rats for $10-27 \mathrm{~h}$ after nerve transection. To maximize the potential for stable recording conditions, the cut nerve was covered with a Vaseline and mineral oil mixture, which prevented accumulation of tissue fluid around the base of the nerve. Furthermore, the tongue was kept in a flow chamber and bathed between stimulation series with $0.01 \mathrm{M} \mathrm{NaCl}$ to resemble natural conditions in the oral cavity. If the taste response declined to zero, the nerve was readjusted or redissected in attempts to learn whether receptors were still functional.

\section{MATERIALS AND METHODS}

Thirteen female, Sprague-Dawley rats weighing $200-300 \mathrm{~g}$ were studied. Rats were anesthetized via an intraperitoneal injection of sodium pentobarbital $(50 \mathrm{mg} / \mathrm{kg}$ body weight) and given supplemental doses as necessary. The rats were tracheotomized, placed on a heating pad and secured in a head holder.

The left chorda tympani nerve was exposed by a lateral dissection of the head, cut near its entrance into the tympanic bulla and then freed from surrounding connective tissue. The nerve was desheathed and placed on a platinum wire electrode connected to an AC preamplifier, with an indifferent electrode in nearby tissue. The nerve was covered with a mixture of about $1: 1$ Vaseline and mineral oil to prevent dehydration. Neural activity from the whole nerve was analyzed by passing the amplified signals through an AC-DC converter (time constant $=0.5 \mathrm{~s}$ ) connected to a rectilinear pen recorder ${ }^{1}$. Once the experiment began, preamplifier and pen re- corder gain settings were not altered. We recorded from rats until a taste response could no longer be obtained or until the animal died (10-27 h).

Stimuli were $0.1 \mathrm{M} \mathrm{NaCl}, \mathrm{LiCl}, \mathrm{KCl}$, and $\mathrm{NH}_{4} \mathrm{Cl}$ dissolved in distilled water and maintained at room temperature during the experiments. The stimuli were applied through a flow chamber which contained the anterior tonguel. During chemical stimulation, the chamber was filled and the flow was stopped for $20 \mathrm{~s}$. Then, stimuli were rinsed by continuously flowing distilled water through the chamber for $20 \mathrm{~s}$. The next stimulus was not applied until 1 min had elapsed.

The stimulation sequence was $0.1 \mathrm{M} \mathrm{NaCl}, \mathrm{KCl}$, $\mathrm{NH}_{4} \mathrm{Cl}, \mathrm{LiCl}$ and $\mathrm{NaCl}$. This entire series was initially applied to the tongue $1 \mathrm{~h}$ after cutting the nerve. Subsequently, the stimulus series was applied every 30 or $60 \mathrm{~min}$. During the interstimulus period the flow chamber was filled with $0.01 \mathrm{M} \mathrm{NaCl}$ which was rinsed with distilled water prior to the next stimulation sequence. Since preliminary experiments demonstrated that stable responses could be obtained for the initial 8-9 h, no recordings were made between 4 and $7 \mathrm{~h}$ after cutting the nerve.

A response was defined as an increase above baseline of the summated neural activity, measured in $\mathrm{mm}$ of pen recorder deflection at $15 \mathrm{~s}$ following stimulus onset, during the 'steady-state' or adapted response. The adapted phase of the response was studied rather than the initial transient because it represents the response at equilibrium and allows direct comparisons with published values from other investigators 1,7 . Examination of raw data records indicated that changes in the transient portion directly paralleled changes in the adapted response, so it was not necessary to analyze both phases of the response.

General changes in response magnitude with time

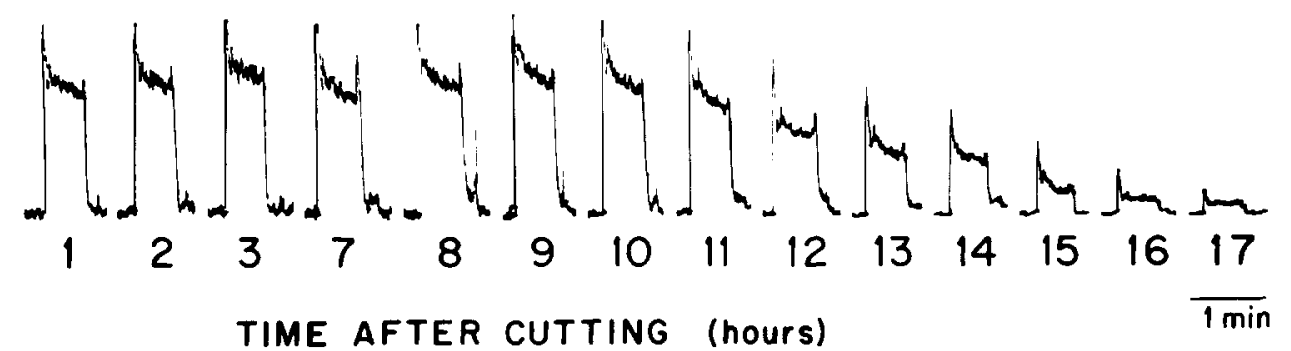

Fig. 1. Integrated responses to $0.1 \mathrm{M} \mathrm{NaCl}$ recorded at 1-17 h after cutting the chorda tympani nerve. Amplifier and pen recorder gain settings were not altered during the experiment. In this animal it is apparent that responses were stable for $10 \mathrm{~h}$. 
were analyzed by expressing each $\mathrm{NaCl}$ response elicited in a specific stimulation period relative to the $\mathrm{NaCl}$ response in the initial stimulation sequence. To compare responses to 4 salts, ratios for each salt were calculated relative to the $\mathrm{NaCl}$ response in the same time period. The magnitude of the $\mathrm{NaCl}$ response was taken as the mean value of the two applications of $\mathrm{NaCl}$ in each stimulation series.

\section{RESULTS}

\section{Effect of nerve transection on $\mathrm{NaCl}$ responses}

To establish general characteristics of the taste response in long-term recordings, we analyzed $\mathrm{NaCl}$ responses. Taste responses to $0.1 \mathrm{M} \mathrm{NaCl}$ were stable for several hours after nerve cut (Fig. 1), and only after about $10 \mathrm{~h}$ did the response begin to decrease. $\mathrm{NaCl}$ response ratios for 6 individual rats are presented in Fig. 2A. In 5 of these animals responses did not begin to decline until 8-10 $\mathrm{h}$ after nerve transection and in one animal stable responses were obtained for $15 \mathrm{~h}$. The individual data points are averaged in Fig. 2B to demonstrate the initial stable phase and subsequent decline. The mean taste response did not decrease below initial magnitude for $10 \mathrm{~h}$ and declined to $50 \%$ of the initial magnitude after $15 \mathrm{~h}$.

In most animals the response magnitude was actually enhanced for a few hours after cutting the chorda tympani (Fig. 2). The degree of enhancement varied and was presumably related to changes in recording conditions. For example, recording resistance might increase as the nerve adheres to the electrode. However, we are not certain why the enhancement occurs. Other investigators also have observed a transitory period of increased responsiveness 13 .

In 7 experiments the nerve slipped from the recording electrode and had to be repositioned, or the response declined substantially and attempts were made to redissect and adjust the nerve. Taste responses obtained after replacing the nerve on the electrode were of a higher magnitude than before the nerve was readjusted, but were never restored to the initial magnitude measured at $1 \mathrm{~h}$, as illustrated for one rat in Fig. 3. This nerve was readjusted twice, once after $10 \mathrm{~h}$ and a second time after $14 \mathrm{~h}$. Although the response had entirely disappeared at $14 \mathrm{~h}$, after further dissection of the nerve a response
A

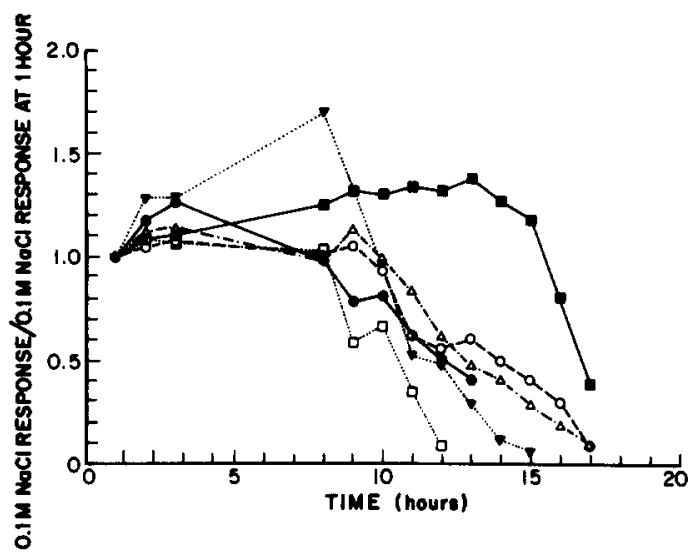

B

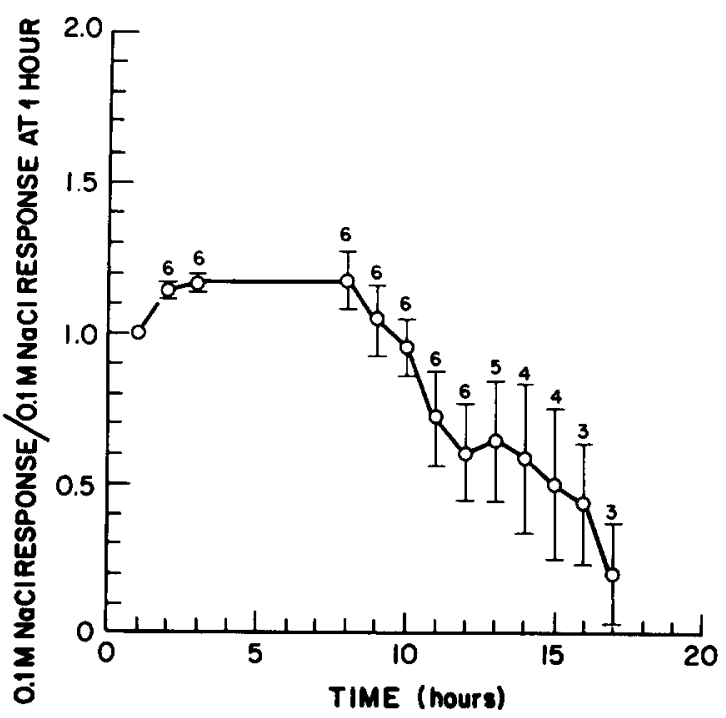

Fig. 2. A: ratios of responses to $0.1 \mathrm{M} \mathrm{NaCl}$ at different times after cutting the chorda tympani nerve, relative to the response at $1 \mathrm{~h}$, for 6 individual rats. Responses remain at or above initial levels for $8-15 \mathrm{~h}$. B: means and standard errors for data in A. Numerals above the standard error bars indicate number of rats on which the average ratio is based. The average chorda tympani response does not decrease for $10 \mathrm{~h}$ after nerve cut; by $15 \mathrm{~h}$, the average response has declined to $50 \%$ of initial mag. nitude.

was obtained. The additional dissection was accomplished by freeing more of the chorda tympani nerve proximal to the tongue, cutting off a small length of the previously dissected distal nerve end, and desheathing the new length of nerve. In our experiments there was usually sufficient nerve length to accomplish this further dissection once. Thus it was not 


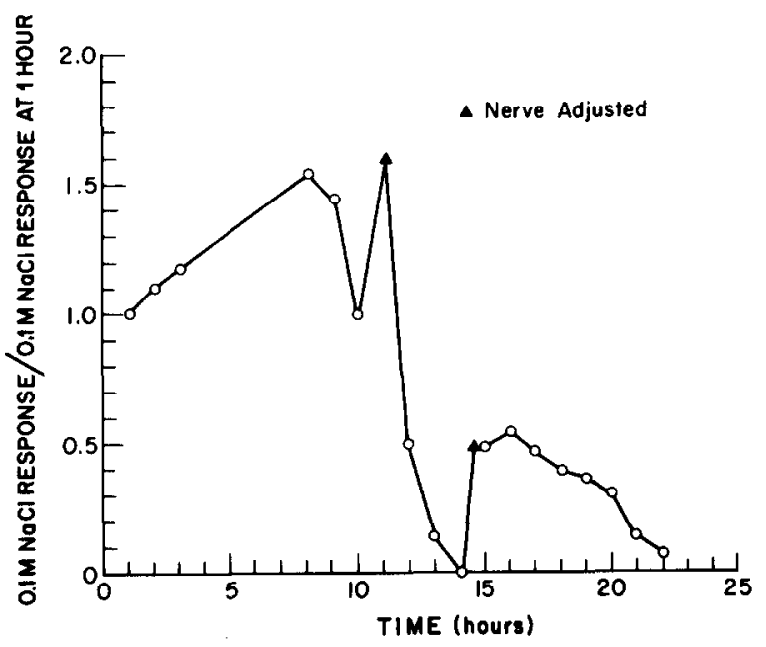

Fig. 3. Response ratios for $0.1 \mathrm{M} \mathrm{NaCl}$ recorded from the chorda tympani at $1-22 \mathrm{~h}$ after nerve cut in one rat. After responses were recorded at $10 \mathrm{~h}$, the nerve slipped from the electrode and was reset. A triangle marks the response after nerve adjustment. The taste response then gradually decreased and disappeared completely at $14 \mathrm{~h}$. The nerve was dissected more proximal to the tongue and reset on the electrode. Taste responses were again obtained (second triangle). There was insufficient nerve length to redissect at $22 \mathrm{~b}$.

possible to repcat this procedure at $22 \mathrm{~h}$ for the preparation in Fig. 3, because there was insufficient nerve for additional dissection.

In 6 other rats in which the distal portion of the chorda tympani was readjusted or redissected the response was improved and in two animals distinct responses remained at $25-27 \mathrm{~h}$; individual data points for these animals and the rat in Fig. 3 are illustrated in Fig. 4A. Means and standard errors for these experiments demonstrate that if the nerve is readjusted, the taste response remains at or above initial values for an average of $12 \mathrm{~h}$ and at or above $50 \%$ of the initial magnitude for $24 \mathrm{~h}$ (Fig. 4B).

\section{Effect of nerve transection on responses to other salts}

At $1 \mathrm{~h}$ after cutting the chorda tympani nerve the order of response magnitudes for the salts was $\mathrm{LiCl}>$ $\mathrm{NaCl}>\mathrm{NH}_{4} \mathrm{Cl}>\mathrm{KCl}$ (Fig. 5), similar to that reported by other investigators ${ }^{1,7}$. Even though response magnitudes declined with time, the order of effective stimulation did not change over several hours (Fig. 5). Mean data for all rats demonstrate that salt responses changed in parallel for at least $19 \mathrm{~h}$ after nerve cut (Fig. 6).

However, in 4 animals in which recordings were
A

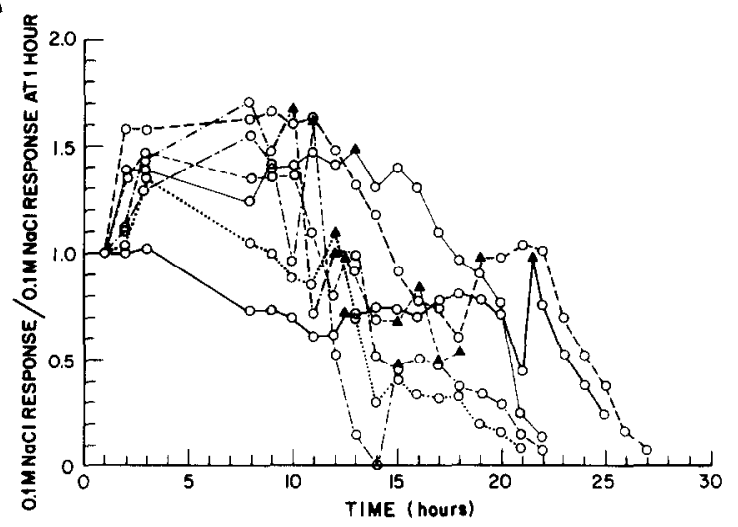

B

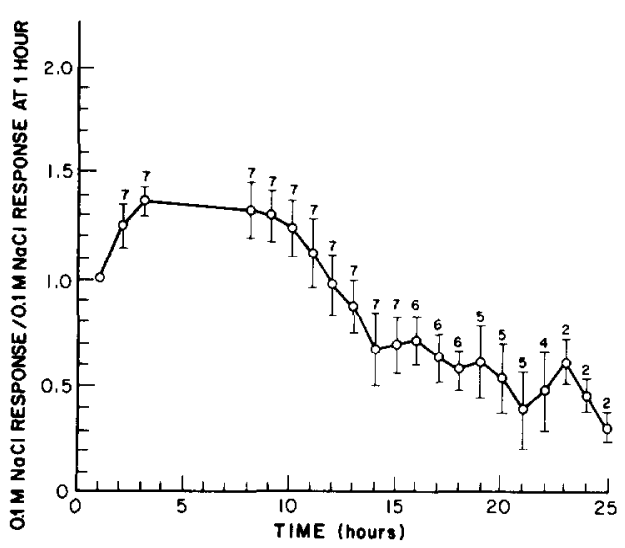

Fig. 4. A: response ratios for $0.1 \mathrm{M} \mathrm{NaCl}$ recorded at different times after cutting the chorda tympani, for 7 rats in which the nerve was reset on the electrode after slipping or further dissection (includes data for the animal in Fig. 3). Ratios obtained after readjustment are marked by triangles. $B$ : means and standard errors of ratios for the individual animals. Numerals above the standard error bars indicate number of animals on which the average is based. Responses remained at or above initial magnitudes for $12 \mathrm{~h}$, and did not decline to $50 \%$ until $21-24 \mathrm{~h}$.

made for a total of 21 up to $27 \mathrm{~h}$, responses to $\mathrm{NaCl}$ and $\mathrm{LiCl}$ apparently declined disproportionately, relative to $\mathrm{NH}_{4} \mathrm{Cl}$ and $\mathrm{KCl}$ (Fig. 6); therefore ratios for $\mathrm{KCl}$ and $\mathrm{NH}_{4} \mathrm{Cl}$ increased. Recordings from one of these rats is presented in Fig. 7A, with data on response magnitudes and ratios over time (Fig. 7B). These records illustrate that the $\mathrm{NaCl}$ and $\mathrm{LiCl}$ responses decreased disproportionately relative to $\mathrm{NH}_{4} \mathrm{Cl}$ and $\mathrm{KCl}$ responses, so that response magnitudes for all 4 salts became more similar with time. 


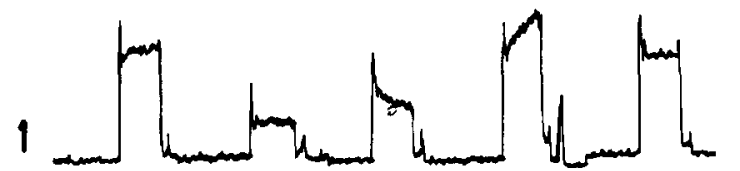

9

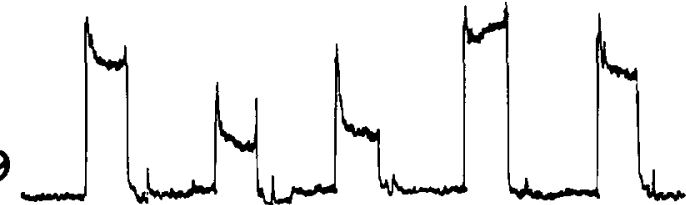

14
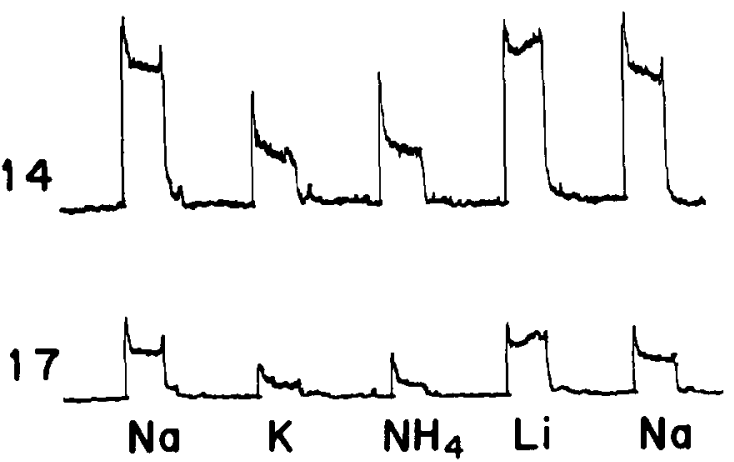

$1 \mathrm{~min}$

Fig. 5. Integrated responses to four $0.1 \mathrm{M}$ monochloride salts $\left(\mathrm{NaCl}, \mathrm{KCl}, \mathrm{NH}_{4} \mathrm{Cl}, \mathrm{LiCl}\right)$ recorded from one rat at different times after cutting the chorda tympani nerve. The number to the left of each record represents time in hours. Amplifier and pen recorder settings were not changed during the experiment. For up to $17 \mathrm{~h}$, responses to the 4 salts altered in parallel.

After redissection at $19 \mathrm{~h}$, response magnitudes to $\mathrm{NaCl}$ and $\mathrm{LiCl}$ were increased, whereas responses to $\mathrm{NH}_{4} \mathrm{Cl}$ and $\mathrm{KCl}$ remained nearly the same as before redissection.

In summary, responses to 4 salt stimuli alter in parallel for at least $19 \mathrm{~h}$ after nerve cut. Beyond that time salt responses may change differentially.

\section{DISCUSSION}

Stable neurophysiological responses can be recorded from the cut chorda tympani nerve for long periods. When the nerve is left undisturbed, the average taste response remains at or above the initial magnitude for $10 \mathrm{~h}$, declines to $50 \%$ by $15 \mathrm{~h}$, and disappears at $12-20 \mathrm{~h}$ after nerve transection. If attempts are made to reposition or redissect the nerve, the response can be preserved for a much longer time. Responses remain at or above initial levels for

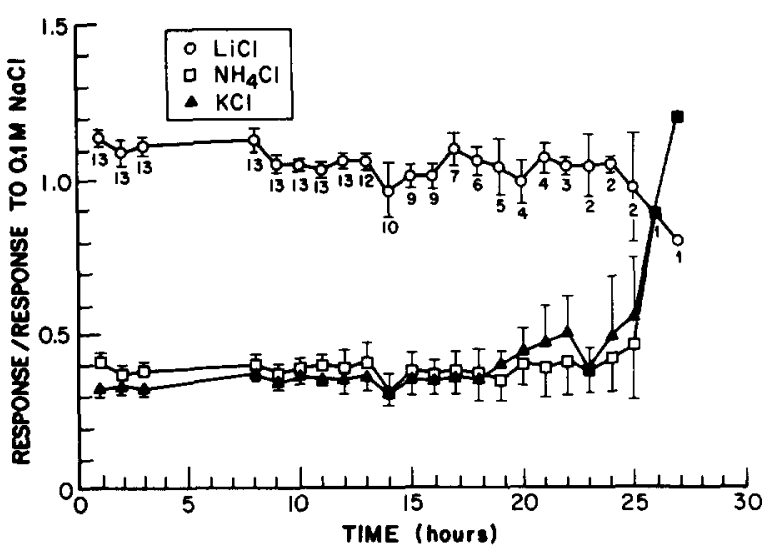

Fig. 6. Means and standard errors of response ratios for $\mathrm{LiCl}$, $\mathrm{NH}_{4} \mathrm{Cl}$ and $\mathrm{KCl}$, relative to the $\mathrm{NaCl}$ response, for several rats at different times after nerve cut. Numerals below the standard error bars indicate number of animals on which the average is based. Taste responses to these salts changed in parallel for $19 \mathrm{~h}$.

$12 \mathrm{~h}$, the $50 \%$ level is not reached until $21-24 \mathrm{~h}$ and a taste response is still obtained in some rats at $21-27 \mathrm{~h}$ after nerve cut. Thus the chorda tympani response to taste stimuli is very stable over a long period, exceeding the length of a usual recording session. Since the taste response is maintained over longer periods after redissecting the nerve, the dissected portion of the chorda apparently deteriorates most rapidly with time whereas the more distal portion survives.

This time course of decline in rat chorda tympani taste responses is very different from that reported by Berland et al. ${ }^{4}$ for gerbil glossopharyngeal nerve. Summated taste responses from the glossopharyngeal declined to $50 \%$ of the initial level within $2 \mathrm{~h}$ after nerve transection. However this is not unexpected since the rate of decline in taste response is apparently dependent on length of the distal nerve stump 5,14 . Stump length in the gerbil glossopharyngeal nerve is 5-10 $\mathrm{mm}^{14}$, whereas length of the chorda tympani in the present experiments is more than $25 \mathrm{~mm}$. Oakley et al. ${ }^{14}$ demonstrated a linear relationship between length of distal nerve stump and time for the taste response to decline to $50 \%$ of initial magnitude. Assuming the same relationship for rat chorda tympani, the time to $50 \%$ decline in $25 \mathrm{~mm}$ is calculated to be $21 \mathrm{~h}$, which is very similar to results we obtained (Fig. 4B). Oakley et al. ${ }^{13}$, however, reported that in some gerbils (usually studied in January to April) a stable taste response was maintained for at least $5 \mathrm{~h}$, so the relation between nerve length and decline of 
A
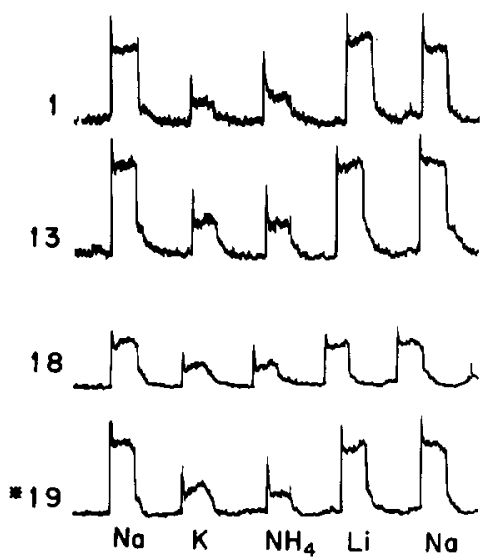
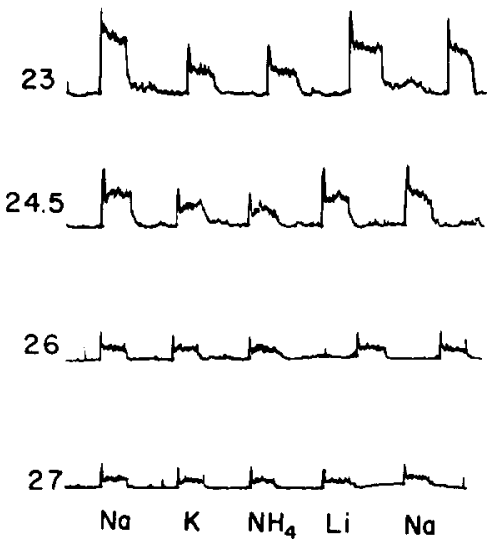

B
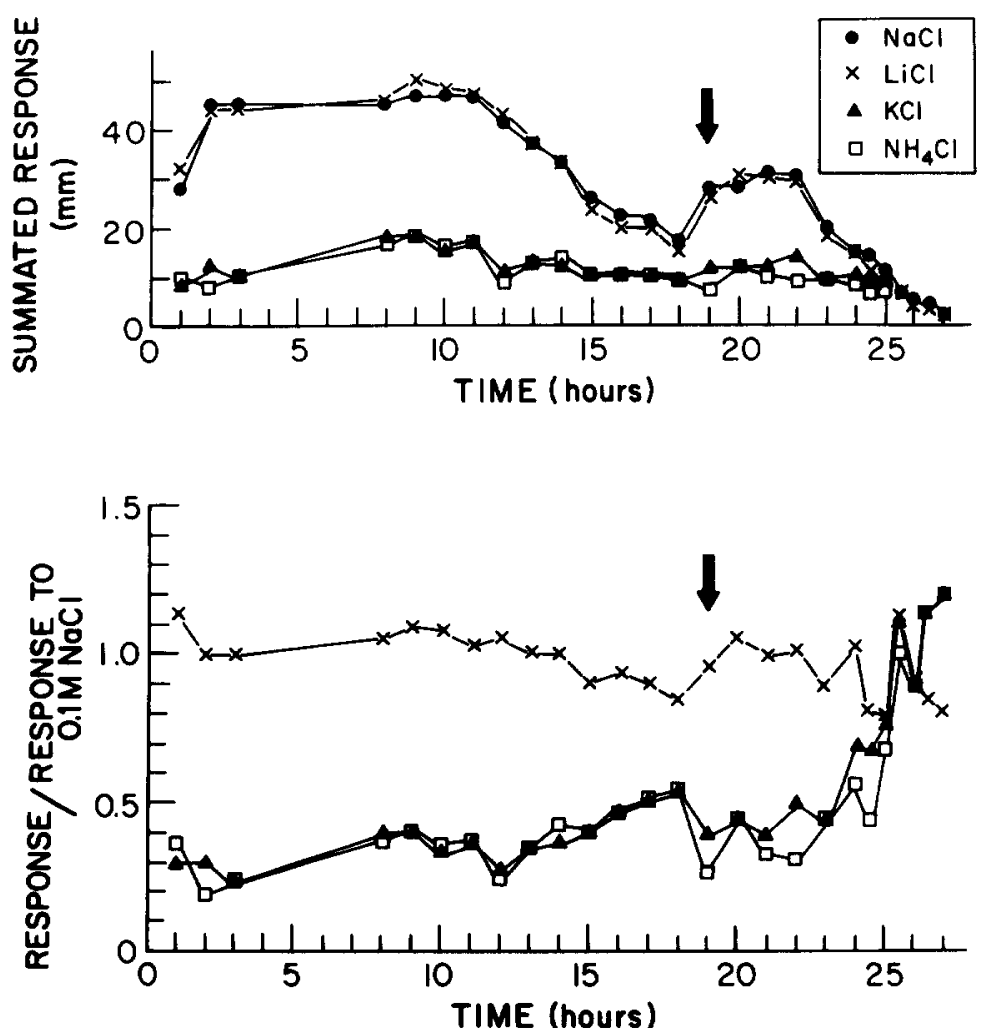

Fig. 7. A: integrated responses to 4 salts at different times after cutting the chorda tympani nerve in one rat. Numbers to the left of each record represent time in hours. The asterisk at $19 \mathrm{~h}$ indicates that the nerve was redissected prior to this recording. After $24 \mathrm{~h}$, responses to $\mathrm{NaCl}$ and $\mathrm{LiCl}$ declined disproportionately to those for $\mathrm{NH}_{4} \mathrm{Cl}$ and $\mathrm{KCl}$. Amplifier and pen recorder settings were unchanged throughout the experiment. B: summated responses in $\mathrm{mm}$ of pen recorder deflection and response ratios relative to $\mathrm{NaCl}$ for the data represented in $\mathrm{A}$. The arrow in each graph indicates data points after nerve redissection. After about $23 \mathrm{~h}$, ratios for $\mathrm{NH}_{4} \mathrm{Cl}$ and $\mathrm{KCl}$ begin to increase as $\mathrm{NaCl}$ responses decline. 
taste response is not consistent in gerbil.

Our data on rat chorda tympani responses are very different from those of Hellekant et al. ${ }^{9}$ who reported that the rat taste response declines to $50 \%$ of initial values after only $5 \mathrm{~h}$ and disappears entirely at $15 \mathrm{~h}$. It is probable that the difference in results between the present study and that of the previous study is due to methodological variables. In the earlier study, data were presented on only one out of 6 rats in which nerve cut was used and subsequent, continuous recordings made from the chorda tympani (Fig. 3 in Hellekant et al. ${ }^{9}$ ). Results on other rats were collected as single data points from animals in which the chorda tympani had been cut in the middle ear, or treated with applications of alcohol or colchicine. In addition, we applied stimuli via a flow chamber and bathed the tongue in $0.01 \mathrm{M} \mathrm{NaCl}$ for the long periods between stimulation sequences. Method of stimulus application and treatment of the tongue between series were not described in the previous paper ${ }^{9}$. It is also perhaps significant that we used a Vaseline/mineral oil mixture on the nerve and electrode, which results in more stable recording conditions than use of mineral oil alone. In summary, we tried to maximize conditions to obtain stable responses and even redissected the nerve if response magnitudes declined substantially, to learn if the taste receptors were still functional.

The fact that any decline occurs in taste responses indicates that either the nerve or taste bud itself is undergoing some degenerative process. It has been demonstrated numerous times that the taste bud degenerates when its afferent supply is interrupted 8 and it is thought that the nerve produces a trophic substance that is responsible for maintaining taste buds. After section of the rat chorda tympani, substantial morphological changes in nerve processes within taste buds are observed at 12-24 $\mathrm{h}^{6}$, and by $21-24 \mathrm{~h}$ we observed a $50 \%$ decline in taste response. It is logical, therefore, to assume that the decline is due to an interruption of the trophic supply as a result of nerve cut $^{13}$. This is supported by the fact that there is no decline in gerbil glossopharyngeal nerve responses if recordings are made from an intact nerve ${ }^{13}$.

However, it is also possible that the dissection, nerve cut, and contact of the nerve with electrodes cause nerve damage and lead to a loss of conduction at the recording site. This seems reasonable since after the taste response declined or even disappeared, it was possible by further dissection to obtain a response once again, although usually at a lower level than initial magnitude. Therefore the overall decline may be attributable to degeneration of the taste bud, but superimposed on this is a secondary effect due to changes in the nerve at the recording site.

\section{Responses to 4 salts}

The gradual decrease in taste responses over about $20 \mathrm{~h}$ was observed not only for $\mathrm{NaCl}$, but also for 3 other monochloride salts. Responses to these salts declined in parallel to each other; therefore, after at least $19 \mathrm{~h}$ of recording, the order of effective stimulation was still $\mathrm{LiCl}>\mathrm{NaCl}>\mathrm{NH}_{4} \mathrm{Cl}>\mathrm{KCl}$. This indicates that specific receptor membrane components interacting with particular monochloride salts degenerate in direct proportion to each other over this time course. However, in two nerves, after recording for $23 \mathrm{~h}$ increases in response ratios were observed for $\mathrm{KCl}$ and $\mathrm{NH}_{4} \mathrm{Cl}$, relative to $\mathrm{NaCl}$. The increasing ratios apparently related primarily to a disproportionate decrease in the $\mathrm{NaCl}$ response. The $\mathrm{LiCl}$ response declined in direct proportion to the $\mathrm{NaCl}$ response and therefore response ratios for $\mathrm{LiCl}$, relative to $\mathrm{NaCl}$, remained stable.

Observed increases in response ratios for $\mathrm{NH}_{4} \mathrm{Cl}$ and $\mathrm{KCl}$, relative to $\mathrm{NaCl}$, are similar to Beidler's ${ }^{2}$ report that after very long recording times the $\mathrm{NaCl}$ response may decline until it is smaller than the $\mathrm{KCl}$ response. It may be that the oldest cells in the taste bud are especially responsive to $\mathrm{NaCl}$ (and $\mathrm{LiCl}$ ) and that these degenerate first ${ }^{3}$. From our studies of development, we have proposed that newly formed cells are more responsive to $\mathrm{NH}_{4} \mathrm{Cl}$ and $\mathrm{KCl}$, but at the end of the cell cycle are more responsive to $\mathrm{NaCl}$ and $\mathrm{LiCl}^{11,12}$. Certainly, the differential decline in $\mathrm{NaCl}$ and $\mathrm{LiCl}$ responses at long periods after nerve transection merits further study.

Alternatively, responses to $\mathrm{NaCl}$ and $\mathrm{LiCl}$ might decline differentially because certain fiber types (e.g. highly Na-responsive) degenerate before other types (e.g. highly $\mathrm{NH}_{4}$-responsive). Or the general ability of the cut nerve to respond with a high frequency might deteriorate, so that large $\mathrm{NaCl}$ or $\mathrm{LiCl}$ responses cannot be generated.

In conclusion, responses to salts recorded from the 
rat chorda tympani remain stable for an average of $12 \mathrm{~h}$ after nerve cut. When responses begin to decline, changes in taste responses to 4 salts occur in parallel, up to at least $19 \mathrm{~h}$. However in some very long recording sessions, $\mathrm{NaCl}$ and $\mathrm{LiCl}$ responses may decline more rapidly than the $\mathrm{NH}_{4} \mathrm{Cl}$ and $\mathrm{KCl}$ responses.

\section{REFERENCES}

1 Beidler, L. M., Properties of chemoreceptors of tongue of rat, J. Neurophysiol., 16 (1953) 595-607.

2 Beidler, L. M., Dynamics of taste cells. In Y. Zotterman (Ed.), Olfaction and Taste I, Pergamon Press, Oxford, 1963, pp. 133-148.

3 Beidler, L. M. and Smallman, R. L., Renewal of cells within taste buds, J. Cell Biol., 27 (1965) 263-272.

4 Berland, D. W:, Chu, J. S., Hosley, M. A., Jones, L. B., Kaliszweski, J. M., Lawler, W. C. and Oakley, B., New approaches to the problem of the trophic function of neurons. In J. LeMagnen and P. MacLeod (Eds.), Olfaction and Taste VI, Information Retrieval, London, 1977, pp. 217-224.

5 Donso, A. and Zapata, P., Effects of denervation and decentralization upon taste buds, Experientia, 32 (1976) 168-175.

6 Farbman, A. I., Fine structure of degeneration taste buds after denervation, J. Embryol. exp. Morph., 22 (1969) $55-68$.

7 Ferrell, M. F., Mistretta, C. M. and Bradley, R. M., Development of chorda tympani taste responses in rat, J. comp. Neurol., 198 (1981) 37-44.

\section{ACKNOWLEDGEMENTS}

This research was supported by N.I.H. Grant DE 05728 and N.S.F. Grant BNS 80-15737 to R.M.B. and C.M.M., and N.I.H., N.I.D.R. Research Career Development Award DE 00066 to C.M.M. We thank Drs. D. Hill and H. Stedman for critical comments on the manuscript.

8 Guth, L., Degeneration and regeneration of taste buds, In L. M. Beidler (Ed.), Handbook of Sensory Physiology, IV: Chemical Senses (Part 2), Taste, Springer-Verlag, Berlin, 1971, pp. 63-74.

9 Hellekant, G., Gopal, V. and Ninomiya, Y., Decline and disappearance of taste response after interruption of the chorda tympani proper nerve of the rat, Acta physiol. scand., 105 (1979) 52-57.

$10 \mathrm{Hill}, \mathrm{D}$. L. and Almli, R., Ontogeny of chorda tympani nerve responses to gustatory stimuli in the rat, Brain $R e$ search, 197 (1980) 27-38.

11 Hill, D. L., Mistretta, C. M. and Bradley, R. M., Developmental changes in taste response characteristics of rat single chorda tympani fibers, $J$. Neurosci., 2 (1982) 782-790.

12 Mistretta, C. M. and Bradley, R. M., Neural basis of developing salt taste sensation: response changes in fetal, postnatal and adult sheep, J. comp. Neurol., 215 (1983) 199-210.

13 Oakley, B., Jones, L. B. and Hosley, M. A., Decline of IXth nerve taste responses following nerve transection, Chem. Senses Flav., 4 (1979) 287-299.

14 Oakley, B., Jones, L. B. and Hosley, M. A., The effect of nerve stump length upon mammalian taste responses, Brain Research, 194 (1980) 213-218. 